UDC 821.133.1(493)-311.1.09Нотомб

DOI https://doi.org/10.32841/2409-1154.2021.49-2.23

\author{
Namestyuk S. V., \\ Candidate of Phylological Sciences, \\ Senior Lecturer at the Department of Foreign Languages \\ Bukovinian State Medical University
}

\author{
Zazulia I. V., \\ Lecturer at the Department of Foreign Languages \\ Bukovinian State Medical University
}

\author{
Teslenko M. O., \\ Lecturer at the Department of Foreign Languages \\ Bukovinian State Medical University
}

\title{
FREUDIAN CATEGORIES AND ALLUSIONS IN AMELIE NOTHOMB'S NARRATIVES
}

Summary. The focus of this paper is the investigation of Amelie Nothomb's (born in 1966) narratives regarding the classical influence as well the use of Freudian categories. The art of the twentieth century is extremely suitable for the aesthetic analysis of the ugly, disgusting, "internal" that is associated with an inner horror. Such aesthetics is present in the work of Amelie Nothomb. This is confirmed by the general characteristics of certain characters (especially negative characters), which regularly appear in the author's novels. In each novel, we will look at how the relationship between beauty and ugliness is distributed and what a proportion is between physical ugliness and mental ugliness. Modern characters of Amelie Nothomb fit harmoniously into the context of romantic traditions.

The aim is a reformulation of the ancient Greek myths and psychoanalysis in Nothomb's narratives as well as to find in Nothomb's novels ancient allusions, the most paradigmatic works concerning this myth in the Classical Era - Oedipus myth. The author transfers the myth into a modern story. Nothomb's recreation of the myth undoubtedly takes influence from Freud's remake of Oedipus myth, although it combines it with classical elements. Consequently, this paper shall elucidate how the parricide and incest taboos are performed in a contemporary work by Amelie Nothomb. Despite the fact this could appear surrealistic, the consecution of the Oedipus Myth/Complex realities is actually the leitmotiv of the storyline. It is at this point, at the very end of the story, when Nothomb exposes her plot spiral. Our interest is to interpret Nothomb's novels as a representative model to explain a more general trend: snobbery driven by the tragedy of egotism. The tendency to extravagances, which has already taken shape in modern literature in the form of the self-destruction which can be considered a way to cleanse your being from toxic waste of being, the establishment of the supremacy of the ideal, ethereal and insignificant over everything else. The distance between the beginning and the end of reading Amelie Nothomb's novels is so short that it suggests that the tendency to conclude may be related to the desire for peace, which Freud called the instinct of death, which in turn generates repression of the mental ego and counter-repression of the body.

Key words: reformulation of the myths, psychoanalysis, Oedipus Complex, Amelie Nothomb, classical reception, Freud.
Introduction. Amelie Nothomb, a contemporary Belgian writer, media star, the writer's acceptance in the West is wellthought-out as a unique sociological phenomenon. The younger she was, the more successful she was. The author's writings are full not only with postmodern kaleidoscopicity, refined and complete elements of narrative discourse, but also with reminiscences of classical literature. Amelie Nthomb's work is studied in academic circles and read by teenagers. Even though, it should be noted that reviews of her work are not always positive, Amelie Nothomb writes numerous real bestsellers a year. The composite structure of the novels and the plot are suitable for film adaptations, plays and even opera interpretations "Les Combustibles". The author's novels are translated into all languages of the world.

As it was mentioned, the censure of the author is not always positive. At times, Amelie Nothomb is considered as a "minor author". According to negative critics, the most important feature of her work is that the whole scheme of her novels is repeated, in particular, copies of the great classical literature. This does not necessarily mean the mediocrity or weakness of the author, yet, we cannot analyze Nothomb's work, ignoring the enormous impact on media society, noting that her novels are often built on well-known and simple schemes, characters (not always) one-dimensional and predictable. The author's style is classic and cultural, sometimes too "comfortable", too obvious and therefore the reader does not have to think much. Paradoxically, readers feel themselves "intellectuals" when reading "these simple words and great ideas". Moreover, the manner of "embracing" novels allows for easy and quick reading, something that is extremely appreciated by the average reader.

It would be a profanation to consider an author who has become a kind of modern life, a minor writer. In our opinion, it is necessary to start from the hypothesis that the more criticism is leveled towards a modern, fashionable author who promotes certain trends in art, builds his own poetics the better.

Problem statement. The main leitmotifs in Amelie Nothomb remain eternal axiological, universal values and classic conflicts: beauty and monster, femininity, crime and punition, childhood, inappropriate relationships, abnormality and more. Amelie Nothomb's bizarre originality lies in her very absurd, almost baroque imagination. It should be noted that the works of Amelie Nothomb are 
autobiographical. The peculiarity of the author is the relentless circulation of the idea of a certain "obsession", writing is a necessity, an insistent idea, it absorbs and directs everything it has, inner anger, resentment, aggression.

It's irrefutable that Amelie Nothomb is an innovative author both in terms of style and in terms of creative phenomenon, in particular. According to her private comments on her novels: "there are certain paradoxes, which can be called "obsessions"'. In her novels, the author points out arguments that we believe are convincing, about the close connection between the experience she had in her childhood and adolescence and the obsessions she describes. There is also an equally interesting connection between the author's obsession and writing style. It seems that we should read Amelie Nothomb's novels as part of a general plan that can definitely be called her great personal conflict. In our work we try to highlight how each novel is necessary and can be read universally through the prism of the author's worldview.

Analysis of recent research and publications. The Italian scientist Domenico Trecocci, following the directives of psychoanalyst Louise J. Kaplan, calls the author's literary work "an autobiographical fetish" [1]. In our opinion, there is a painful sensitivity in the style of the author that is the source of inspiration and gives the writer a certain confidence, from which follows her admiration. The best way of comprehending Amelie Nothomb's novels is the reading from the point of view of psychoanalytic literary criticism, which is genetically related to the directions of literary criticism and criticism, where the main subject is the author, presented in the whole set of facts of biographical, psychological, ideological, aesthetic and creative plans. All-pervading binary oppositions, for example, the trauma of the lost realm of childhood, the first menstrual cycle and the shock of nature associated with sexual attraction to a young man, behavioral disorders associated with body change in adolescence and an deceptive antagonist of consciousness. And so the double enemy is not "somebody else", but a part of itself, the so-called "alter ego". According to O. Makarevich, the binary archetype of thinking is a key semiotic code of classical European culture, the basis of problematic European thinking and, consequently, the core of all its discursive practices. One of the philosophical problems of the literature of the second half of the XXth century is the desire to avoid this binary worldview and remove the pairwise opposition of archetypes. The most common is the path followed by Nietzsche, borrowing from Eastern cultures the idea of a circle, the so called "eternal return". However, French literature and philosophy offer another way to solve this problem: they try to change the relationship between opposing and non-existent without each other binary concepts and symbols of culture, changing their internal relationships [2]. Indeed, we can say that Nothomb's novels are formed in these categories - creation of some raw materials, not fully developed sinister creations - the second "I". Therefore, when Amelie Nothomb says that the "I" is not just another, an alient, but many others, we must think of these others as persecutors, which in the finale are each of us. In his seminal work, "Amelie Nothomb. Il corpo espiatorio", Domenico Trecozzi calls the author's writing style minimalist and invasive, that all her work corresponds to what can be called an anorexic script. However, in our opinion, the internal tension that arises from the quietness that lives inside the "I", "each of us", is the reader must be eliminated, and this is through a mechanism that psychologists call active, a way to cleanse your being from toxic waste of being, the establishment of the suprem- acy of the ideal, ethereal and insignificant over everything else [3], which twists himself to banish one or all of the parts to the stage, as happens, for example, in "The Man of Fire", which is why the best formula for reflecting Nothomb's inner dimension - as she herself says in "Love Sabotage" - is the Ego living in permanent. It is in this sense that the equivalence between minimalist style in literature and anorexic aesthetics in life can be found, since in both cases the categorical imperative is a being who announces his last desire, allowing himself to contemplate a manifestation of refusal capable of filling the void prevails in our modern imagination. This explains the fact that if the heroes of the novels do not accept their bodies, it is because they are a reflection of their mother [4]. It is Amelie who does not accept herself, her body, her appearance, condemning herself to the indignation of envy experienced by true beauty. Think, for example, of the nonconformist posture that her characters choose in novels, if the taste of the ugly prevails, it is because we are faced with a strategy of pride that incurs resentment and purposefully opposes the pursuit of beauty because it cannot take advantage of it. That is why, if in her novels Amelie is doomed to desire, she does so by accepting masochistic humiliation, as in the case of the "Antichrista" or in the case of the "Love Sabotage" and in "Astonishment and Trembling". Thanks to this operation to transform values, Amelie can disguise her revolt and overcome the earthly order of matter thanks to the ideal investment of writing, which gives her an invaluable surplus of life.

As for the inadequacies that Amelie is happy to express in her personal theatrical work through crucis, "they are there for all to see, printed in black on white and now in different languages. Just think of the depressed inner universe that results from the loss of the realm of childhood. We must not forget that our "little plague" envied the girls who in Japan regarded divinity and who devoted all their future efforts to this goal. And then there is the mistake of the mother, who refuses to give her much more love, humiliation and masochistic ridicule" [5]. When you seem to read the end of a novel and then see it begin again somewhere else, it is as if each of them was part of a whole, "personal novel", which is then a whole "autobiography as a fetish".

As it was mentioned, Amelie Nothomb is one of the most popular contemporary authors writing in French and associate of the Academie royale de langue et de littératures françaises de Belgique. Nothomb's vaste productivity covers a wide range of plots and takes its influences from numerous cultures reaching from Japanese to classical literature. In the case of "Tuer le père", the author uses the Greek myth of Oedipus and renovates it into a contemporary story.

Consequently, the point of this item will not be only in finding Freudian insights but the comparison between Nothomb's novel and the classical Oedipus myth. This restitution of the myth definitely takes Freud's new version of the Oedipus story as its initial point, although it combines it with more classical elements. Accordingly, this paper shall make clear how the parricide and incest taboos are performed in a contemporary work by Nothomb in an creative, perceptive and penetrating style. Through her works, Nothomb has formed her very own literary universe. She develops her specific and at many times poetical - understandings of other cultures: North American, European, as well as Eastern culture. She generates her own mythology by uniting ancient sagas and legends with contemporary facts. Her work covers a wide range of literary genres: adult fairy tales, tragicomedy and autofiction. Therefore, her corpora is 
a anthology of suspenseful stories, absurd humor, mad dialogues, and literary erudition with autobiographical touches, which she inventively combines with her real-life interviews ensuring her readers are kept in suspense. Since debutant novel, "Hygiène de l'assasin" ("Hygiene and the Assassin") [6], the classical references are present in her works: "Tenez, prenons Homère: en voilà un qui n'a jamais été aussi célèbre. Or, vous en connaissez beaucoup, de vrais lecteurs de la vraie Iliade et de la vraie Odyssée? Une poignée de philologues chauves, voilà tout (...) Et c'est précisément pour cette excellente raison qu'Homère est la référence" [7]. Moreover, "Hygiène de l'assasin" is almost entirely written in dialogues, succeeding the structure and dynamics of a Platonic dialogue" [8].

Further classical references can be found in other first novels of the author such as "Attentat" ("Attack", 1997), where there is an reading of the classical Orpheus myth by Nothomb: "Si Orphée avait été l'assassin d'Eurydice, peut-être aurait-il réussi à la ramener des Enfers". In addition, the heading of Nothomb's previous novel, "Électre" ("Electra", 1996), raises to another classical myth that was changed into a Freudian complex, even though the plot of the novella has no connection with the myth. Furthermore to the numerous classical references in Nothomb's plots, she has written some stories unambiguously linked to classical influences: "Les Catilinaires" ("The Stranger Next Door", 1995), "Péplum" ("Peplum", 1996), "Tuer le père", 2011 as well "Le crime du comte Neville" ("The Crime of Count Neville", 2015). These novels could be separated into two groups. In the first group, the plot is closely related to the ancient world and Classical studies: "Les Catilinaires" and "Peplum". "Les Catilinaires" describes the story of a couple, Émile, a retired Latin and Ancient Greek teacher, and his wife Juliette, who after the retirement want to enjoy their love in an idyllic location, but their peace will be disturbed by their neighbor, Mr. Bernardin [9]. In parallel to the main plot, "Les Catilinaires" is a imitation on teaching and studying Classical Philology. For its part, "Peplum" is a dystopia, where the time traveler A. N. - Amelie Nothomb's alter ego - visits a future Roman Pompei [10].

"Tuer le père and" and "Le crime du comte Neville" are in turn tranformations of classical myths and tragedies. "Tuer le père" is a reconfiguration of Oedipus myth and Sophocles' Oedipus Rex and "Le crime du comte Neville" is a reconfiguration of Iphigenia myth.

In the case of "Tuer le pére", Nothomb writes a modern novel that is grounded on a thriller. The Belgian author takes inspiration from the contemporary Freud's reformulation of Oedipus myth: the Oedipus Complex, which was reaffirmed and restructured by Lacan. This reformulation of the myth has been utilized by contemporary literature since the 20th century, for example in Lawrence's "Sons and Lovers", 1913, a masterpiece of English Literature.

Conclusions. Nothomb uses this modern reconsideration of Oedipus Myth/Complex in a literary way: the son, who is in love with his mother, has a competitive impulse towards his father. Nothomb is cognizant to the ancient myth and references to it can be seen in many of her passages. Her style of accomplishing the combination of ancient myth and Freud's reconfiguration is both refined and complex, on literary and meta-literary levels. On the one hand, there is a plot of the novel which is strictly related to the Oedipus Myth/Complex. On the other hand, there are numerous allusions to classical literary world and myths, not exclusively the Oedipus myth: "Depuis Nietzsche, on sait que Dieu danse. (...) C'est le combat sans vainqueur entre Dionysos et Apollon, l'alternance continuelle du danger et de la maitrise, de la folie et de l'intelligence, du désir et de la plénitude". Joe Whip is a teenager evicted from his house by his mother, who continues to give him money in the form of child support. He never knew his father and due to this, he has always suffered from the sense of paternal absence. The name of his mother is Cassandra. This is the first classical reference: Cassandra in classical mythology is the one who knows the truth, vs. Oedipus, and tries to enlighten others, yet no one is willing to listen to her prophecies. In "Tuer le pére" Cassandra preserves some features from the classical character and is described as: "Cassandra, elle, parlait continuellement, sans doute parce que le silence la crispait".

After the study of Amelie Nothomb's narrative a sum of conclusions can be drawn. The writer repeatedly plays with several levels of reality in her story. The recipient must identify the myth so that the plot makes sense. She presents a modern story, at the same time as preserving a constant presence of the ancient myth in the context.

It is due to this specific "incest" written in a way that evades being too grotesque, that Nothomb is able to break the taboo. The novel is in fact a philosophical paradox, a metaphysical and metaphorical echo on fatherhood, the connection between parents and children and what legitimates paternity. It is not only about sexuality and sensuality but also about destiny, the mysterious truth and an different reality exposed to the addressees.

\section{References:}

1. Treccozzi D. (2011) Amelie Nothomb o Il corpo espiatorio. Arezzo : Zona, $176 \mathrm{p}$.

2. Макаревич O. (2010) Бинарные категории мышления как основа философского мировосприятия в литературных сказках Амели Нотомб и Мишеля Турнье. Вестник Нижегородского университета им. Н.И. Лобачевского. С. 42.

3. Sofe A. (2012) "Sigmund Freud's psychoanalytic theory Oedipus complex: A critical study with reference to D.H. Lawrence's Sons and Lovers". In Internal Journal of English and Literature, 3, no. 3, 60-70.

4. Freud S. (2008) Three essays on the theory of sexuality. Translated from German: prof. Yuri Kuznetsov, Anatoly V. Furman. Journal of Psychology and Society. № 4. P. 45-91.

5. De Decker J. (2016) Discours of the reception of Amelie Nothomb at the Royal Academy of Belgium with. Paris: Albin Michel, 36 p.

6. Nothomb A. 1992. Hygiène de l'assasin. Paris: Albin Michel.

7. Nothomb A. 1996. Électre. Paris: Stock.

8. Gorrara C. 2000. "Speaking volumes: Amelie Nothomb's Hygiène de l'assassin". In Women's Studies International Forum, 23, no. 6, 761-766.

9. Dewez N. 2016. "Péplum, le voyage dans le temps d'A.N.", Textyles 48, 93-104.

10. Álvares C. 2015. "Le Voisin indélogeable : le vide pesant de l'idiotie dans Les catilinaires, d'Amelie Nothomb" In Figuras do idiota, edited by Álvares, Cristina, Curado, Ana Lúcia and Guimarães de Sousa, Sérgio, 107-118.

Наместюк С. В., Зазуля І. В., Тесленко М. О. Контамінація фрейдизму та античних міфів у наративах Амелі Нотомб

Анотація. Основна увага нашої роботи присвячена дослідженню наративів Амелі Нотомб (1966 року народження), їх класичному впливу, а також торкається фрейдистського ракурсу аналізу текстів авторки. Письменниця неодноразово грає 3 кількома рівнями реальності у своїй iсторії. Одержувач має визначити міф, щоб сюжет мав сенс. Вона представляє сучасну історію, водночас збері- 
гаючи постійну присутність античного міфу в контексті. Ця робота є аналізом переформулювання давньогрецьких міфів та психоаналізу авторкою. Романістка переносить міф у сучасну історію. Мистецтво XX століття надзвичайно підходить для естетичного аналізу потворного, огидного, «внутрішнього», що пов'язане з внутрішнім жахом. Така естетика присутня у творчості Амелі Нотомб. Це підтверджується загальною характеристикою певних персонажів (особливо негативних персонажів), які регулярно з'являються в авторських романах. У кожному романі ми розглянемо, як розподіляються відносини між красою та потворністю та яка пропорція між фізичною і психічною потворністю. Сучасні персонажі Амелі Нотомб гармонійно вписуються в контекст романтичних традицій. Тому метою цієї роботи є знайти в романах Нотомб античні алюзії найбільш парадигматичних творів, дотичних до найпотужнішого міфу класичної епохи - Едіпового міфу. На відтворення міфу в наративах Амелі Нотомб, безсумнівно, впливає фрейдистська реформуляція Едіпового міфу, хоча авторка поєднує його $з$ класичними елементами. Отже, в цій статті буде з'ясовано перформанс табу паррициду та інцесту в сучасній інтерпретації Амелі Нотомб. Відстань між початком і кінцем прочитання романів Амелі Нотомб настільки коротка, що припускаємо, що їі тенденція до висновку може бути пов'язана з прагненням до миру, яке Фрейд називав інстинктом смерті, що своєю чергою породжує пригнічення психічного его і контррепресія свого Я. Тому наш інтерес полягає в тому, щоб інтерпретувати романи Нотомб як репрезентативну модель для пояснення більш загальної тенденції: снобізму, зумовленого трагедією егоїзму, тенденції до надмірностей, що вже склалася в сучасній літературі у формі самознищення, яку можна вважати способом очищення себе від токсичних відходів буття, встановлення верховенства ідеального, ефірного та незначного над всіма.

Ключові слова: переформулювання міфів, психоаналіз, Едіпів комплекс, Амелі Нотомб, класична рецепція, Фрейд. 